Tạp chí Các Khoa học về Trái Đất, 38 (1), 46-58

\begin{tabular}{c} 
Viện Hàn lâm Khoa học và Công nghệ Việt Nam \\
Tạp chí Các Khoa học về Trái Đất \\
WAST) \\
Website: http://www.vjs.ac.vn/index.php/jse \\
\hline
\end{tabular}

\title{
Đặc điểm đứt gãy hoạt động và tai biến xói lở ở các vùng cửa sông ven biển Bắc Trung Bộ Việt Nam
}

\author{
Phạm Văn Hùng*, Nguyễn Công Quân \\ Viện Địa chất, Viện Hàn lâm Khoa học và Công nghệ Việt Nam
}

Chấp nhận đăng: 10 - 3 - 2016

ABSTRACT

The characteristics of active faults and erosion hazard in coastal-river mouth zones of North Central Vietnam

Integrated analysis of the latest research results allowed for defining the characteristics and mechanism of active faults and their association to the coastal-river mouth erosion in North Central Vietnam.

In the North Central region, the fault zones are NW-SE, NE-SW, submeridian and subparallel oriented. Of these the NW-SE faults play the key role in forming modern structural plan in the area. Under recent geodynamical setting of submeridian compression, the stress field is of strike slip-extensional type, the NW-SE is a normal dextral strike slip, the NE-SW is a normal sinistral strike slip, and the submeridian fault system is acting as normal strike slip faults.

Fault activity and modern subsidence movement of the crust is one of the factors causing erosion in coastal estuaries in North Central. Most of the strongly and intensively eroded coastal segments (in Hai Loc-Hau Loc, Hai Thinh-Tinh Gia, Dien Hai, Dien Kim, Dien Thinh-Dien Chau, Canh Duong, Quang Phuc-Quang Trach, Thuan An - Huong Tra and Huong Thuy) are those situated near an operational NW-SE fault heading to the sea, or at the intersection of active faults. The stronger active faults, the more coastal erosion.

(C)2016 Vietnam Academy of Science and Technology

\section{Mở đầu}

Vùng cửa sông ven biển (VCSVB) Bắc Trung Bộ chạy dài khoảng $550 \mathrm{~km}$, thuộc vùng đồng bằng ven biển các tỉnh từ Thanh Hóa đến Thừa Thiên Huế; có điều kiện tự nhiên phong phú và đa dạng; có tiềm năng to lớn về tài nguyên khoáng sản; chiếm vị trí quan trọng trong sự phát triển kinh tế xã hội (KT-XH) ở miền Trung nói riêng, nước ta nói chung. Trong những năm gần đây, dải đất này thường xuyên chịu tác động tiêu cực của các tai biến địa chất, gây hậu quả nghiêm trọng cho đời sống KT-XH của cư dân địa phương, trong đó, có hoạt động tích cực của các đứt gãy kiến tạo và xói

*Tác giả liên hệ, Email: phamvanhungvdc@gmail.com lở bờ sông, bờ biển (Phạm Văn Hùng, 2008; Nguyễn Văn Hùng, 2002; Bùi Văn Thơm, 2002).

Để phục vụ phát triển bền vững $\mathrm{KT}$-XH và phòng tránh giảm nhẹ thiên tai, tại khu vực này đã có một số công trình nghiên cứu và đạt được những kết quả nhất định. Tuy nhiên, cho đến nay, nghiên cứu đặc điểm hoạt động hiện đại của đứt gãy và mối liên quan với các tai biến địa chất, đặc biệt là đối với xói lở bờ sông, bờ biển còn tồn tại và rất cần làm sáng tỏ. Do phần lớn các công trình khoa học chỉ đề cập đến yếu tố ngoại sinh và nhân sinh trong sự hình thành và phát triển xói lở bờ sông, bờ biển (Nguyễn Văn Cư và Phạm Huy Tiến, 2003; Lê Xuân Hồng, 1996); trong khi các yếu tố nội sinh, như chuyển động hiện đại vỏ Trái Đất, hoạt động của các đứt gãy kiến tạo hiện đại đóng 


\section{P.V. Hùng và nnk/Tạp chí Các Khoa học về Trái Đất, Tập 38 (2016)}

vai trò quan trọng, quyết định mức độ xói lở bờ biển chưa được làm sáng tỏ ở khu vực này. Do chưa đánh giá đầy đủ, đúng mức vai trò của các yếu tố phát sinh xói lở, nên các giải pháp áp dụng phòng chống xói lở ở vùng cửa sông ven biển Bắc Trung Bộ vẫn chưa thực sự hiệu quả.

Xuất phát từ nhu cầu cấp thiết của thực tiễn đặt ra, công trình này trình bày những kết quả nghiên cứu mới về tính chất, cơ chế hoạt động của các đứt gãy và mối quan hệ với hiện tượng xói lở ở vùng cửa sông ven biển Bắc Trung Bộ, phục vụ dự báo và đề xuất giải pháp phòng chống tai biến xói lở bờ sông, bờ biển ở khu vực này.

\section{Phương pháp nghiên cứu và cơ sở tài liệu}

\subsection{Phuơng pháp nghiên cứu}

Trên thế giới cũng như ở Việt Nam, các phương pháp nghiên cứu đứt gãy hoạt động và mối liên quan với tai biến địa chất đã được đề cập trong nhiều công trình. Trong công trình này, các phương pháp nghiên cứu áp dụng bao gồm: phân tích viễn thám, khảo sát thực địa, phân tích biến dạng địa mạo địa chất, kiến tạo vật lý và phân tích tổng hợp.

- Phương pháp phân tích tổng hợp tài liệu hiện có: các tài liệu nghiên cứu trước đây về đứt gãy hoạt động và hiện trạng xói lở bờ sông bờ biển ở khu vực này rất phong phú và đa dạng. Phân tích tổng hợp các tài liệu này cho bức tranh chung về đặc điểm hoạt động của các đứt gãy và hiện trạng phân bố xói lở vùng cửa sông ven biển.

- Phương pháp phân tích giải đoán ảnh viễn thám, đặc biệt là viễn thám phân giải cao (thông qua các dấu hiệu trực tiếp: tôn ảnh, hoa văn, độ xám,...; gián tiếp: dạng địa hình, sông suối,...) cho phép xác lập hiện trạng xói lở bờ sông, bờ biển; đồng thời xác lập sự phân bố và đặc điểm của đứt gãy hoạt động.

- Phương pháp khảo sát thực địa đã cho phép thu thập các tài liệu về vị trí, kích thước của các điểm xói lở; tính chất và cơ chế hoạt động của các đứt gãy trong khu vực nghiên cứu.

- Phương pháp phân tích tổng hợp đánh giá mối liên quan của đứt gãy hoạt động với xói lở bờ sông, bờ biển.

\subsection{Co' sở tài liệu}

Các tài liệu về đứt gãy hoạt động và hiện trạng xói lở vùng cửa sông ven biển Bắc Trung Bộ là rất phong phú và đa dạng bao gồm:

- Các tài liệu về hiện trạng xói lở, bồi tụ, địa mạo, cấu trúc tân kiến tạo và đứt gẫy hoạt động ở các VCSVB thu thập được từ các công trình của Nguyễn Văn Cư và Phạm Huy Tiến (2003), Lê Xuân Hồng (1996), Phạm Văn Hùng (2006), Nguyễn Văn Hùng (2002), Bùi Văn Thơm (2002),....

- Công trình này sử dụng các tư liệu viễn thám bao gồm: Landsat-7, Landsat-8, SPOT-5 có độ phân giải $10-15 \mathrm{~m}$; bản đồ địa hình tỷ lệ $1: 50.000$ các năm 1965, 2002, 2010. Kết quả phân tích ảnh viễn thám đã xác lập hiện trạng xói lở và đặc điểm phân bố của đứt gãy hoạt động vùng cửa sông ven biển Bắc Trung Bộ.

- Các tài liệu khảo sát ngoài thực địa, cho phép xác định vị trí, kích thước điểm xói lở, các đứt gãy hoạt động ở các vùng cửa sông ven biển sông Mã, Sông Cả, Sông Thạch Hãn và sông Hương.

- Các tài liệu phân tích tổng hợp biến dạng địa mạo, địa chất, kiến tạo khu vực nghiên cứu và quy luật phân bố xói lở bờ sông, bờ biển, cho phép các tác giả xác định đặc điểm hoạt động của đứt gãy và mối quan hệ của chúng với quá trình xói lở bồi tụ bờ sông, bờ biển vùng cửa sông ven biển Bắc Trung Bộ.

\section{3. Đặc điểm đứt gãy hoạt động}

Trên khu vực nghiên cứu, các công trình nghiên cứu trước đây đã đề cập đến các đứt gãy hoạt động với cường độ và biên độ khá mạnh mẽ (Phạm Văn Hùng, 2006; Nguyễn Văn Hùng, 2002; Bùi Văn Thơm, 2002). Trên vùng cửa sông ven biển Bắc Trung Bộ chạy từ Thanh Hóa đến Thừa Thiên - Huế phân bố các đoạn đầu mút đông nam của các đới đứt gãy hoạt động có phương tây bắcđông nam (TB-ĐN) chạy từ lãnh thổ Lào vào Việt Nam ra đến bờ biển. Ngoài ra, các đứt gãy có phương đông bắc-tây nam (ĐB-TN), á kinh tuyến và á vỹ tuyến phân bố rải rác ở 2 đầu phía bắc và nam khu vực Bắc Trung Bộ. Trong đó, phải kể đến các đoạn đầu mút của các đới đứt gãy Sơn La-Bỉm Sơn (ĐSL-BS), Sông Mã (ĐSM), Sông Cả (ĐSC), Rào Nậy (ĐRN), Khe Giữa-Vĩnh Linh (ĐKG-VL), Đa Krông-Huế (ĐĐR-H) (hình 1). 
Tạp chí Các Khoa học về Trái Đất, 38 (1), 46-58

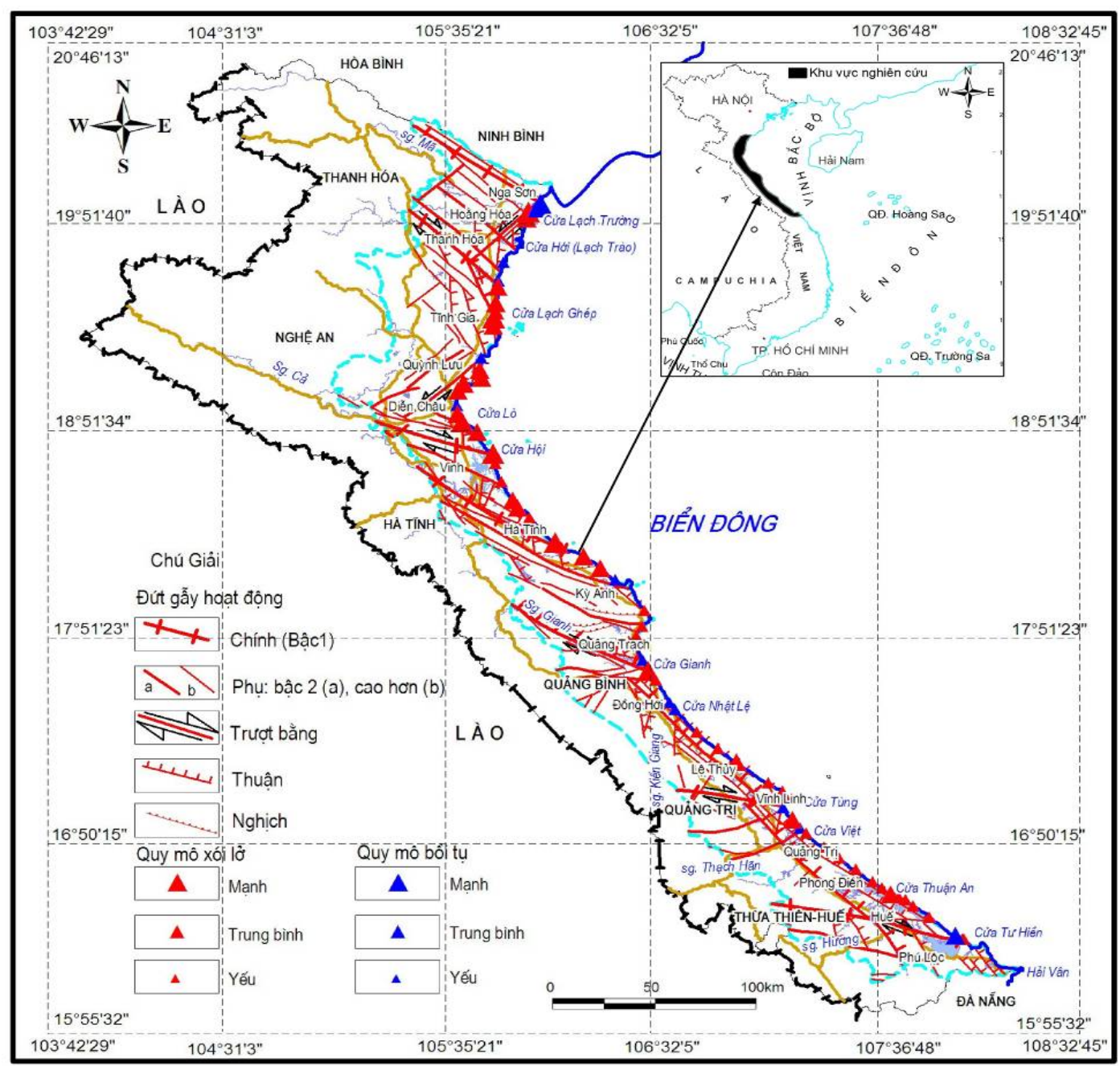

Hình 1. Bản đồ hiện trạng xói lở - bồi tụ các vùng cửa sông ven biển Bắc Trung Bộ

Đới đứt gãy Sơn La - Bỉm Sơn (ĐSL-BS) dài hơn $360 \mathrm{~km}$ bắt đầu từ Nậm Nèn (Lai Châu) cắt qua Tuần Giáo, Thuận Châu, kéo dài về phía đông nam, qua Mai Sơn, Mộc Châu, Mai Châu, Bỉm Sơn và ra đến bờ biển ở Nga Sơn (tỉnh Thanh Hóa). Từ Nậm Nèn đến Tuần Giáo, đới đứt gãy là dải trũng rộng $5-6 \mathrm{~km}$, nằm giữa núi Huổi Long cao 1500-2000m ở phía tây nam và cao nguyên Tủa Chùa cao gần $1500 \mathrm{~m}$ ở phía đông bắc. Từ Tuần Giáo đến Chiềng Cọ dài hơn $55 \mathrm{~km}$ đới đứt gãy chạy dọc sườn dải núi thấp nằm giữa một bên là dãy Su Sung Chảo Chai cao 1500-2000m ở phía tây nam và một bên là các cao nguyên đá vôi cao 600-700m thuộc các huyện Thuận Châu, Mai Sơn ở phía đông bắc. Từ Chiềng Cọ đến Mai Châu dài hơn $100 \mathrm{~km}$, đới đứt gãy trùng với dải địa hình thấp nằm giữa một bên là các dải núi $\mathrm{Phu} \mathrm{Ca} H i e ̂ n, ~ P h u$ Sang, Phan Cô Phiên, Phan Cô Tan với độ cao $>1000 \mathrm{~m}$ ở phía tây nam và một bên là dải núi đá vôi cao hơn $1200 \mathrm{~m}$ ở phía đông bắc. Các đứt gãy là các thung lũng suối hẹp và kéo dài hoặc là các vách đá vôi dựng đứng. Từ Mai Châu đến bờ biển, đới đứt gãy cắt dọc theo sườn đồi, thung lũng hẹp thẳng, giữa một bên là dãy núi đá vôi cao 500 $1000 \mathrm{~m}$ ở phía đông bắc và một bên là đồng bằng thấp trải rộng về phía nam đến tận bờ biển. 


\section{P.V. Hùng và nnk/Tạp chí Các Khoa học về Trái Đất, Tập 38 (2016)}

Đới đứt gãy Sông Mã (ĐSM) dài gần $400 \mathrm{~km}$ bắt đầu từ Mường Ảng chạy theo phương TB-ĐN, dọc theo sông Mã, qua thị trấn Sông Mã, Chiềng Khương (tỉnh Sơn La) sang Lào, sau đó, lại vào Việt Nam ở Mường Lát, rồi chạy qua Lang Chánh tỏa về phía đông nam thành một dải hình quạt, qua các huyện Ngọc Lạc, Thọ Xuân, Như Xuân ra tận bờ biển ở Tĩnh Gia. Trong khu vực nghiên cứu, từ Lang Chánh đến bờ biển, đứt gãy là tập hợp các dải trũng thung lũng thấp, kéo dài. Đứt gãy chính chạy dọc theo sườn đồi thấp dưới $100 \mathrm{~m}$ bị phân cắt ngang mạnh, rộng $3,5-4 \mathrm{~km}$, kéo dài từ Lang Chánh, dọc thung lũng sông Âm đến Bái Thượng, qua Yên Cát, Bến En cắt dọc theo rìa phía tây đồng bằng các huyện Nông Cống, Tĩnh Gia ra đến biển ở cửa Lạch Ghép. Ngoài ra, đới đứt gãy này gồm một số đứt gãy phụ nằm ở phía đông bắc đứt gãy chính, chạy dọc theo thung lũng karst hẹp kéo dài từ Lang Chánh đến Ngọc Lạc theo phương TBĐN, tiếp đến là sườn dải địa hình thấp, trũng đầm hồ và lòng sông cổ ở Thọ Xuân rồi chạy ra bờ biển. Các đứt gãy phụ khác nằm ở phía tây nam đứt gãy chính, chạy dọc theo sườn dải đồi thấp dưới $100 \mathrm{~m}$ bắt đầu từ Bái Thượng qua Như Xuân, Như Thanh về Tĩnh Gia ra đến bờ biển.

Đới đứt gãy hoạt động Sông Cả (ĐSC), gồm có một đới đứt gãy chính Kỳ Sơn - Cửa Lò bắt đầu từ phía đông bắc cao nguyên Xiêng Khoảng (Lào) chạy theo phương á vĩ tuyến vào biên giới Việt Nam ở phía nam cửa khẩu Nậm Cắn qua thị trấn Mường Xén (Kỳ Sơn - Nghệ An), chạy dọc theo sông Nậm Mô và sông Cả, qua Đôn Phục (Con Cuông), Vinh Thọ (Anh Sơn) sau đó chạy dọc theo phần hạ nguồn thung lũng sông Con đến thị trấn Tân Kỳ, thị trấn Yên Thành và ra tới biển ở khu vực Cửa Lò. Đoạn từ Mường Xén đến Khe Bố có phương tây bắc - đông nam, đoạn còn lại từ Khe Bố đến Cửa Lò ngả dần sang phương á vĩ tuyến. Tổng chiều dài của đới đứt gãy khoảng $400 \mathrm{~km}$; phần chạy trên lãnh thổ Việt Nam khoảng $200 \mathrm{~km}$. Ngoài đứt gãy chính kể trên, ĐSC còn các đứt gãy nhánh khác. Đứt gãy nhánh Huổi Nhị - Xiêng Líp có phương á vĩ tuyến với chiều dài $70 \mathrm{~km}$, bắt đầu từ Huổi Nhị qua bản Vệ đến Xiêng Líp. Đứt gãy nhánh Khe Bố - Nghi Xuân, tách ra khỏi đới chính ở khu vực Khe Bố. Đới đứt gãy có phương tây bắc - đông nam với chiều dài khoảng $130 \mathrm{~km}$, bắt đầu từ Khe Bố chạy dọc thung lũng sông Cả, rồi men theo sườn đông bắc núi Hồng Lĩnh ra tới biển ở khu vực xã Liên Đông (Nghi Xuân - Hà Tĩnh). Đứt gãy nhánh Khe Bố - Hà Tĩnh, tách ra khỏi đới chính ở khu vực tây nam Khe Bố. Đới đứt gãy có phương tây bắc - đông nam với chiều dài khoảng $150 \mathrm{~km}$, bắt đầu từ phía tây nam Khe Bố chạy theo bờ trái sông Giang sau đó men theo bờ phải sông Cả đến thị trấn Đức Thọ rồi tiếp tục chạy dọc theo thung lũng sông Nghèn đến thị xã Hà Tĩnh ra tới biển ở Cửa Sót.

Đới đứt gãy hoạt động Rào Nậy (ĐRN) chạy từ lãnh thổ Lào vào biên giới Việt Nam ở địa bàn huyện Hương Sơn, rồi dọc sông Rào Nậy ra đến biển ở cửa Gianh. ĐRN gồm các đứt gãy chính và đứt gãy nhánh. Đứt gãy chính Rào Vàng - Cửa Gianh (ĐcRV-CG) bắt đầu từ sườn phía tây nam dãy núi Phu Xa Leng (thuộc lãnh thổ Lào), cách biên giới Việt Nam khoảng $80 \mathrm{~km}$, vào Việt Nam ở khu vực Cửa Rào Vàng (huyện Hương Sơn, tỉnh Hà Tĩnh), theo phương TB-ĐN qua thị trấn Hương Sơn, Hương Khê, Tuyên Hóa rồi chạy dọc bờ phải thung lũng sông Rào Nậy, ra tới biển ở phía nam Cửa Gianh. Chiều dài đới đứt gãy khoảng $230 \mathrm{~km}$, trên lãnh thổ Việt Nam dài khoảng $150 \mathrm{~km}$. Đứt gãy nhánh Hương Khê - Ròn, được tách ra từ đới chính Rào Vàng - Cửa Gianh ở khu vực xã Hương Giang (Hương Khê) chạy dọc theo thung lũng sông Rào Trị, Rào Con và phần thượng nguồn sông Rào Pheo, qua các xã Kỳ Thượng, Kỳ Lâm, Kỳ Lạc (Kỳ Anh), Quảng Hợp, Quảng Liên (Quảng Trạch) rồi ra biển ở khu vực cửa Ròn, dài khoảng $80 \mathrm{~km}$.

Đới đứt gãy hoạt động Khe Giữa - Vĩnh Linh (ĐKG-VL), bắt đầu từ giữa cao nguyên Xiêng Khoảng (Lào) sang lãnh thổ Việt Nam ở khu vực phía tây nam núi Cô Ta Run, qua khu vực Khe Giữa, Khe Bang (huyện Lệ Thủy), phía bắc thị trấn Bến Quang (huyện Vĩnh Linh) rồi kéo ra tới biển ở cửa Tùng. Chiều dài của đới đứt gãy khoảng $400 \mathrm{~km}$. Trên lãnh thổ Việt Nam dài $120 \mathrm{~km}$. Phương của đới là tây, tây bắc - đông, đông nam.

Đới đứt gãy hoạt động Đa Krông-Huế (ĐĐK$\mathrm{H})$ dài trên $600 \mathrm{~km}$, được bắt đầu từ đông nam Thà Khẹt (Lào) vào lãnh thổ Việt Nam ở bản $\mathrm{A}$ Dua (phía bắc Lao Bảo) qua cầu treo Đa Krông, chạy dọc theo một đoạn sông Đa Krông qua bản Ta Leng (huyện Đa Krông), sau đó tiếp tục chạy dọc theo phần thượng nguồn sông Ô Lâu đến xã Phong Xuân (huyện Phong Điền) rồi chạy men theo chân 
sườn phía đông của các dải núi Ông Già, núi Đông, núi Bàn đến Hòa Vân (huyện Hương Điền). Đến đây, đới đứt gãy cắt qua đồng bằng và ra tới biển ở cửa Tư Hiền. Chiều dài của đới đứt gãy trên lãnh thổ Việt Nam khoảng 170km. Đoạn từ A Dua - Phong Xuân đới đứt gãy phát triển theo phương TB-ĐN, đoạn còn lại phát triển theo phương gần á vĩ tuyến. Từ Hoà Vân, đới đứt gãy tách thêm một nhánh theo phương TB-ĐN đến Phú Lộc với chiều dài khoảng $50 \mathrm{~km}$.

Trên địa hình, các đới đứt gãy thể hiện là tập hợp dày sít các thung lũng thẳng, vách dốc kiến tạo, hoặc là các dải địa hình trũng thấp, đầm lầy phân bố dạng tuyến; đặc biệt, chúng thể hiện là các dải dị thường mật độ lineamen-đứt gãy. Các đới đứt gãy hoạt động ĐSL-BS, ĐSM, ĐSC, ĐRN, ĐKG-VL và ĐĐR-H kéo dài phương TB-ĐN chạy từ phía tây bắc ra phía đông nam khu vực nghiên cứu, cắt ra bờ biển. Chúng là những dải dị thường mật độ lineamen $\left(0,8-1,4 \mathrm{~km} / \mathrm{km}^{2}\right)$. Các đới đứt gãy có phương ĐB-TN, á kinh tuyến và á vỹ tuyến thể hiện là những dải dị thường mật độ lineamen $(0,6$ $1,2 \mathrm{~km} / \mathrm{km}^{2}$ ). Đặc điểm động học và cơ chế hoạt động của các đứt gãy vùng cửa sông ven biển Bắc Trung Bộ được phân tích đánh giá trên cơ sở phân tích tổng hợp các kết quả nghiên cứu địa mạo, địa chất, hình hài kiến trúc và kiến tạo vật lý. Mặt trượt các đới đứt gãy hoạt động ĐSL-BS, ĐSM, ĐSC, ĐRN, ĐKG-VL và ĐĐR-H đổ về phía đông bắc với góc cắm $60^{\circ}-80^{\circ}$. Kết quả phân tích khe nứt kiến tạo bằng các phương pháp kiến tạo vật lý cho thấy, trong các đá basalt Pliocen - Đệ Tứ, trầm tích Neogen và các đá cổ hơn lộ ra ở khu vực này đã khôi phục được trường ứng suất kiến tạo (TUSKT) Pliocen - Đệ Tứ tương ứng với TUSSKT hiện đại lãnh thổ Việt Nam nói chung (Bùi Văn Thơm, 2002). Như vậy, pha kiến tạo muộn xảy ra vào Pliocen - Đệ Tứ - Hiện đại trong bối cảnh động lực với các trục ứng suất nén ép cực đại phương á kinh tuyến, tách giãn cực đại phương á vĩ tuyến và trung gian gần thẳng đứng. Tính chất của TUSKT là trượt - giãn. Trong bối cảnh địa động lực hiện đại, nén ép phương á kinh tuyến, kiểu trường “Trượt-Giãn”, các đứt gãy phương TB-ĐN hoạt động trượt bằng phải-thuận, ĐB-TN hoạt động trượt bằng trái-thuận, phương á kinh tuyến hoạt động thuận và các đứt gãy phương á vỹ tuyến hoạt động trượt nghịch. Dọc theo các đứt gãy phát triển các kiến trúc tách sụt lấp đầy trầm tích Đệ Tứ - Hiện đại theo phương á kinh tuyến. Phân tích các biến dạng địa mạo, địa chất, hình hài kiến trúc dọc theo các đứt gãy cũng cho các kêt quả tương tự. Theo các dấu hiệu địa mạo, địa chất và kiến trúc, biên độ dịch trượt ngang dọc theo các đứt gãy ĐSL-BS, ĐSM, ĐSC, ĐRN, ĐKG-VL và ĐĐR-H đạt trung bình $300-500 \mathrm{~m}$ với tốc độ chừng $2-4 \mathrm{~mm} /$ năm trong Đệ Tứ muộn. Chiều rộng vùng ảnh hưởng động lực của các ĐSL-BS, ĐSM, ĐSC, ĐRN, ĐKG-VL và ĐĐR-H đạt khoảng từ 3-5 đến 5-8km (Nguyễn Văn Hùng, 2002; Bùi Văn Thơm, 2002). Khi cắt ra bờ biển, chiều rộng vùng ảnh hưởng động lực đứt gãy tăng lên.

Hiện nay, các đứt gãy vẫn đang hoạt động, thể hiện rất rõ trên các dấu hiệu địa mạo, địa chất hiện đại, trên các dữ liệu ảnh viễn thám, địa hóa khí đất, địa nhiệt, xuất lộ nguồn nước khoáng nóng và tai biến địa chất (Nguyễn Văn Hùng, 2002; Bùi Văn Thơm, 2002; Nguyễn Trọng Yêm và nnk, 2006). Chúng là nơi có tiềm ẩn phát sinh động đất Msmax $=5,0-5,5$; Iomax $=6-7$ và $h=15-20 \mathrm{~km}$ (Nguyễn Đình Xuyên, Nguyễn Ngọc Thủy, 1997). Trong thực tế đã ghi nhận các trận động đất có $\mathrm{Ms}<5,5$, các điểm nứt đất, nứt-trượt lở đất, xói lở bờ sông, bờ biển diễn ra phổ biến ở khu vực Bắc Trung Bộ (Nguyễn Văn Cư và Phạm Huy Tiến, 2003; Nguyễn Văn Hùng, 2002; Bùi Văn Thơm, 2002). Các trận động đất ghi được có chấn tâm phân bố dọc các đới đứt gãy Sông Mã, Sông Cả và Rào Nậy. Các điểm nứt đất, trượt lở đất phân bố dọc các đới đứt gãy chính trong khu vực. Tại xã Diễ்n Thành (huyện Diễn Châu), vết nứt phương á kinh tuyến dài $100 \mathrm{~m}$ trên địa hình tích tụ bằng phẳng, hiện nay nước chảy theo khe nứt này đã làm mở rộng chiều rộng của khe nứt $2-3 \mathrm{~m}$ sâu $1,5-2 \mathrm{~m}$. Điểm nứt xảy ra trên đứt gãy phụ phương á kinh tuyến thuộc đới đứt gãy Khe Giữa-Vĩnh Linh. Tại thôn Tiên Lai xã Vĩnh Lâm (huyện Vĩnh Linh), nứt đất xuất hiện vào 6/1993 tạo thành dải dài 500$700 \mathrm{~m}$, rộng $10-15 \mathrm{~m}$, chạy theo phương á vĩ tuyến. Trên đới đứt gãy Đa Krông-Huế, nứt đất xảy ra ở Hương Hồ (huyện Hương Trà), Thành Nội (thành phố Huế), Thủy Châu (Hương Thủy), Phú Hồ (Phú Vang). Ngoài ra, hoạt động hiện đại của các đới đứt gãy còn biểu hiện ở sự xuất lộ nước khoáng nóng và dị thường khí đất $(\mathrm{Rn}, \mathrm{Hg})$. Trong khu vực này, xuất lộ các nguồn nước khoáng nóng có khả năng sử dụng phục vụ đời sống KT-XH: Kim Sơn (Hương Sơn), Khe Bang (Lệ Thủy), Quảng An (Quảng Điền), Hương Vân (Hương Trà). 


\section{P.V. Hùng và nnk/Tạp chí Các Khoa học về Trái Đất, Tập 38 (2016)}

\section{Hiện trạng xói lở vùng cửa sông ven biển Bắc Trung Bộ}

\subsection{Hiện trạng xói lở bò̀ biển Bắc Trung Bộ}

Hiện trạng xói lở bờ biển được nghiên cứu trên cơ sở tổng hợp các tài liệu hiện có, phân tích ảnh viễn thám và khảo sát thực địa, được đánh giá theo bảng phân cấp xói lở bờ biển của Ban chỉ đạo các dự án nghiên cứu dự báo phòng chống xói lở bờ sông, bờ biển (Nguyễn Văn Cư và Phạm Huy Tiến, 2003; Nguyễn Trọng Yêm và nnk, 2006).

\subsubsection{Khu vực tù̀ Thanh Hóa đến Hà Tình}

Dọc dải bờ biển từ Thanh Hóa đến Hà Tĩnh, quá trình xói lở phân hóa rất rõ nét, hình thành những đoạn có tốc độ xói lở rất khác nhau.

Tại Quảng Xương, Hoằng Hóa, hiện tượng xói lở bờ biển diễn ra mạnh mẽ có ảnh hưởng rất lớn tới an toàn các tuyến đê ngăn nước lũ. Hiện tượng xói lở cục bộ diễn ra ở một số nơi trên đoạn bờ biển thuộc huyện Hậu Lộc và Hoằng Hóa, dài hàng chục kilomet. Xói lở ở đoạn bờ biển Hậu Lộc lấn sâu vào đất liền từ $250 \mathrm{~m}$ đến $300 \mathrm{~m}$ trong vòng 50 năm (1965-2015) với tốc độ trung bình 4-5 m/năm. Đoạn bờ biển ở Hoằng Hóa, trong hàng chục năm qua, xói lở bờ biển trung bình từ $150 \mathrm{~m}$ đến $250 \mathrm{~m}$ với tốc độ xói lở khoảng 3-5 m/năm. Đoạn bờ dài hơn $6 \mathrm{~km}$ nằm trên địa phận các xã từ Hoằng Thanh tới Hoằng Tiến, hình thành vùng xói lở rộng trung bình $40 \mathrm{~m}$ và rộng nhất tới $125-130 \mathrm{~m}$; tốc độ xói lở bờ đạt 2-3m/năm. Tại khu vực Lạch Bạng - Thanh Hóa, tốc độ xói lở đạt tới 5$10 \mathrm{~m} /$ năm.

Trên địa phận Nghệ An-Hà Tĩnh, tại khu vực Nghi Xuân, tốc độ xói lở đạt tới 10-13 m/năm; khu vực phía bắc cửa Sót, Đông Trì đến Đông Quan, tốc độ xói lở từ 3 đến $10 \mathrm{~m} / \mathrm{năm}$.

\subsubsection{Khu vực tù̀ Quảng Bình đến Thù̀a Thiên - Huế}

Trên dải bờ biển từ Quảng Bình đến Thừa Thiên-Huế, quá trình xói lở bờ biển diễn ra khá phức tạp và phân bố thành từng đoạn có tốc độ xói lở khác nhau.

Trên địa phận tỉnh Quảng Bình, các đoạn bờ xói lở mạnh với tốc độ $5-7 \mathrm{~m} /$ năm phân bố ở xã Quảng Đông, Quảng Phú và Cảnh Dương (huyện
Quảng Trạch), Nhân Trạch (huyện Bố Trạch). Các đoạn bờ xói lở trung bình với tốc độ xói lở 3$5 \mathrm{~m} /$ năm phân bố ở các xã Thanh Trạch, Hải Trạch, Đức Trạch, Trung Trạch, Đại Trạch và Nhân Trạch (nam cửa Dinh) dài khoảng $20 \mathrm{~km}$; xã Hải Ninh (thôn Tân Định, Tân Hải) xói lở trên cả đoạn dài $5 \mathrm{~km}$; ở bắc cửa Gianh, một phần ở xã Ngư ThủySen Thủy và kéo dài sang xã Vĩnh Thái (Quảng Trị). Các đoạn bờ xói lở yếu với tốc độ $<3 \mathrm{~m} / \mathrm{năm}$ phân bố ở Quảng Phúc và phía bắc cửa Gianh.

Trên địa bàn tỉnh Quảng Trị, các đoạn bờ xói lở yếu với tốc độ $<2 \mathrm{~m} /$ năm phân bố ở Mũi Si-Mũi Hàu và đoạn bờ cát xã Gio Hải-Triệu An (bắc và nam cửa Việt). Đoạn bờ xói lở trung bình với tốc độ $3-4 \mathrm{~m} /$ năm chỉ gặp một đoạn bờ biển ở cửa Tùng dài khoảng $7 \mathrm{~km}$. Đoạn bờ xói lở mạnh với tốc độ $>5 \mathrm{~m} /$ năm phân bố ở huyện Gio Linh, bắc Vĩnh Thái dài $6-7 \mathrm{~km}$. Đoạn bờ xói lở rất mạnh với tốc độ $>7 \mathrm{~m} /$ năm dài $1500 \mathrm{~m}$ ở nam xã Vĩnh Thái gồm các thôn Tân Thuận, Tân Hòa.

Ở tỉnh Thừa Thiên-Huế, các đoạn bờ xói lở yếu với tốc độ xói lở $<3 \mathrm{~m} /$ năm phân bố ở Quảng Điền, Hương Trà (các xã Quảng Ngạn, Quảng Công) dài $12 \mathrm{~km}$. Các đoạn bờ xói lở trung bình với tốc độ 3$5 \mathrm{~m} /$ năm phân bố ở các xã Điền Hoà, Phong Hải, Vinh Xuân, Vinh Thanh, Vinh An (dài trên 13km) và đoạn từ cửa Tư Hiền tới mũi Chân Mây Tây (dài $3 \mathrm{~km}$ ). Đoạn bờ xói lở mạnh với tốc độ $>6 \mathrm{~m} /$ năm phân bố ở huyện Phú Vang. Điển hình là các đoạn Hải Dương - Phú Thuận - Phú Hải - Phú Diên nằm ở hai bên cửa Thuận Ản, đoạn ở xã Vĩnh Hải (bờ đê chắn vịnh Cầu Hai).

\subsection{Hiện trạng xói lở ở các của sông}

4.2.1. Của Hới (tên gọi khác là của Lạch Trào, tỉnh Thanh Hóa) và Của Lạch Trường

Cửa Hới là cửa chính thuộc hệ thống sông Mã, nằm giữa địa phận huyện Hoàng Hóa (bờ bắc) và thị xã Sầm Sơn (bờ nam). Ngoài cửa Hới, sông Mã còn một số cửa phụ khác như cửa Lạch Trường, cửa sông Lèn,... nằm ở địa phận các huyện Hậu Lộc và Nga Sơn. Biến động lòng sông xẩy ra chủ yếu ở các đoạn sông uốn khúc. Hiện tượng xói lở bờ sông diễn ra phân dị với tốc độ khác nhau theo không gian.

Cửa Hới là cửa chính thuộc hệ thống sông Mã, nằm giữa địa phận huyện Hoàng Hóa (bờ bắc) và thị xã Sầm Sơn (bờ nam). Biến động lòng sông xẩy ra chủ yếu ở các đoạn sông uốn khúc. Phía trong sông xói lở diễn ra mạnh mẽ hơn ngoài cửa sông. Bên trong cửa sông, xói lở bờ đạt $300 \mathrm{~m}$ với tốc độ 
Tạp chí Các Khoa học về Trái Đất, 38 (1), 46-58

$6 \mathrm{~m} /$ năm. Phía ngoài cửa sông ven bờ biển, xói lở bờ biển trung bình $150 \mathrm{~m}-250 \mathrm{~m}$ với tốc độ xói lở khoảng $3-5 \mathrm{~m} /$ năm. Khu vực ven biển phía bắc cửa Hới diễn ra hiện tượng xói lở - bồi tụ xen kẽ. Đáng chú ý là đoạn bờ xói lở dài hơn $6 \mathrm{~km}$ nằm trên địa phận các xã từ Hoằng Thanh tới Hoằng Tiến, hình

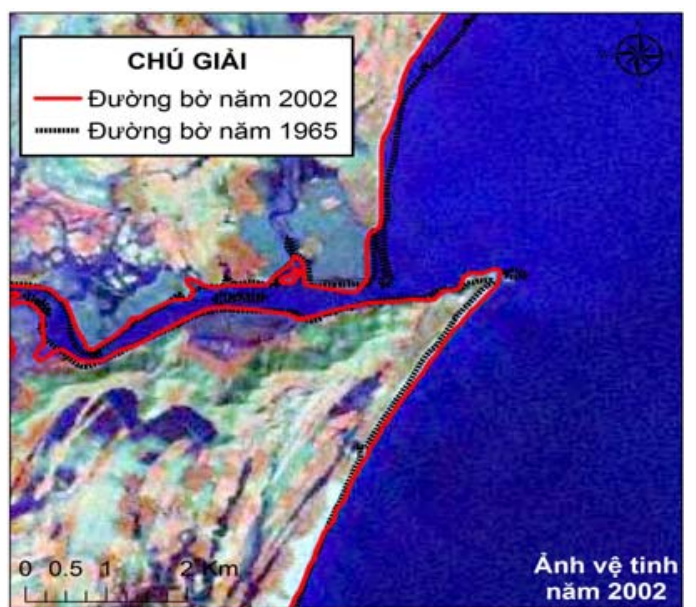

Cửa Lạch Trường thành vùng xói lở rộng trung bình $40 \mathrm{~m}$ và rộng nhất tới 125-130m; tốc độ xói lở bờ đạt 2-3m/năm. Trên khu vực ven biển phía nam cửa Hới diễn ra hiện tượng xói lở-bồi tụ xen kẽ trên đoạn bờ dài từ 1,2 đến $3 \mathrm{~km}$. Tốc độ xói lở bờ đạt $3-4 \mathrm{~m} / \mathrm{năm}$ (hình 2,3).

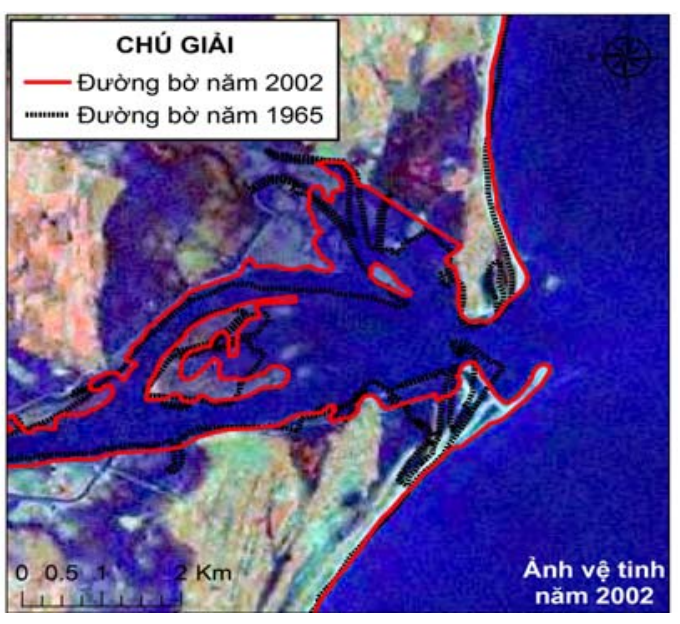

Cửa Hới

Hình 2. Biến động đường bờ trên ảnh viễn thám Landsat-7 vùng cửa sông ven biển sông Mã

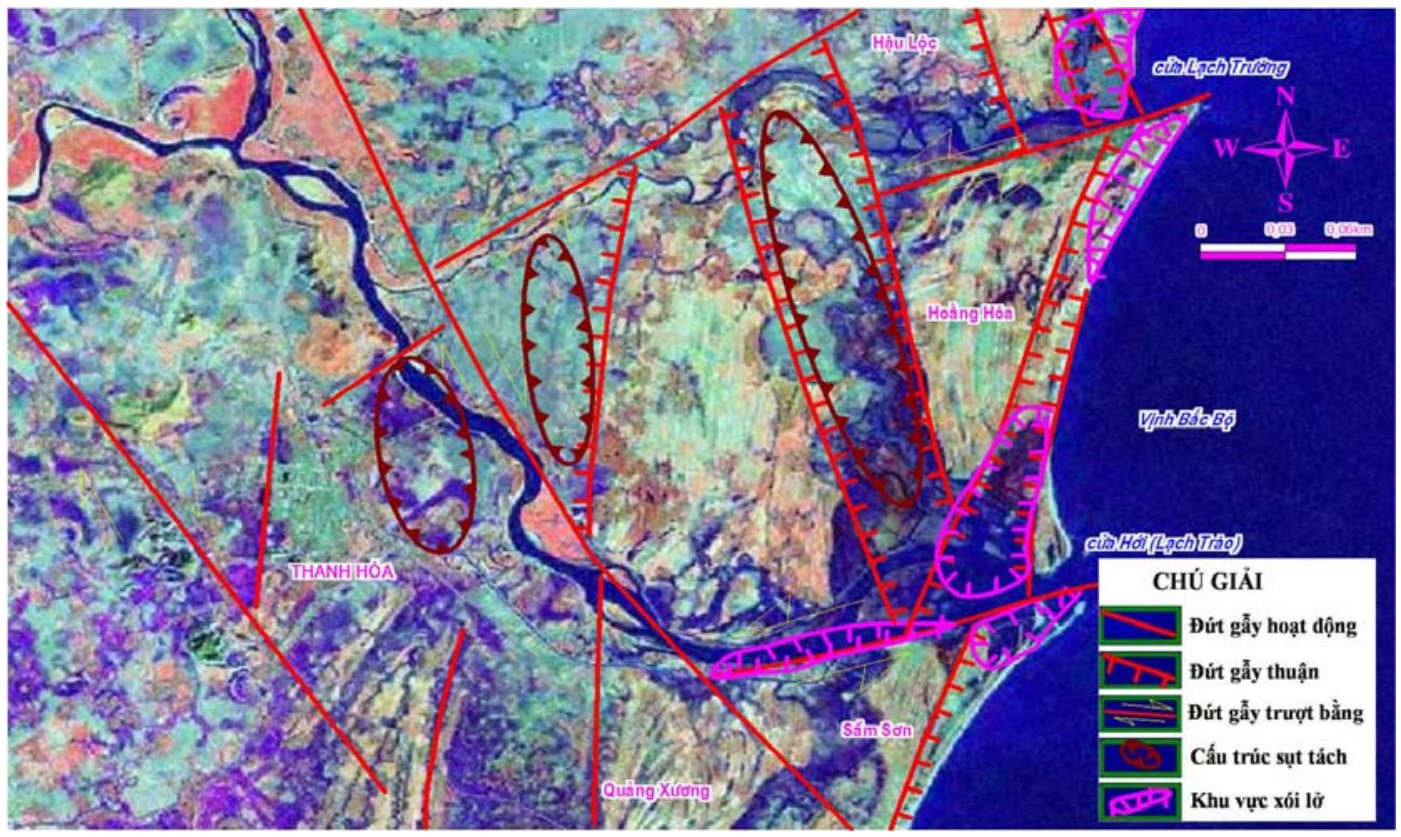

Hình 3. Sơ đồ hiện trạng xói lở và đứt gãy hoạt động khu vực Cửa Hới - Lạch Trường, Sông Mã (ảnh Landsat-8) 


\section{P.V. Hùng và nnk/Tạp chí Các Khoa học về Trái Đất, Tập 38 (2016)}

Quá trình xói lở diễn ra khá phức tạp ở cửa Lạch Trường. Bên cạnh bồi tụ phát triển, hiện tượng xói lở cục bộ diễn ra ở một số nơi trên đoạn bờ biển cửa Lạch Trường, dài hàng chục kilomet. Tốc độ xói lở ở đoạn bờ biển phía bắc cửa Lạch Trường mạnh hơn đoạn phía nam. Xói lở bờ lấn sâu vào đất liền từ $250 \mathrm{~m}$ đến $300 \mathrm{~m}$ trong vòng 50 năm (1965-2015) với tốc độ trung bình 4-5m/năm.

4.2.2. Cửa Hội (sông Cả, thuộc các tỉnh Nghệ An và Hà Tĩnh)

Cửa Hội thuộc hệ thống sông Cả, có vị trí nằm giữa địa phận thị xã Cửa Lò (bờ bắc) và huyện Nghi Xuân (bờ nam) (hình 4, 5).

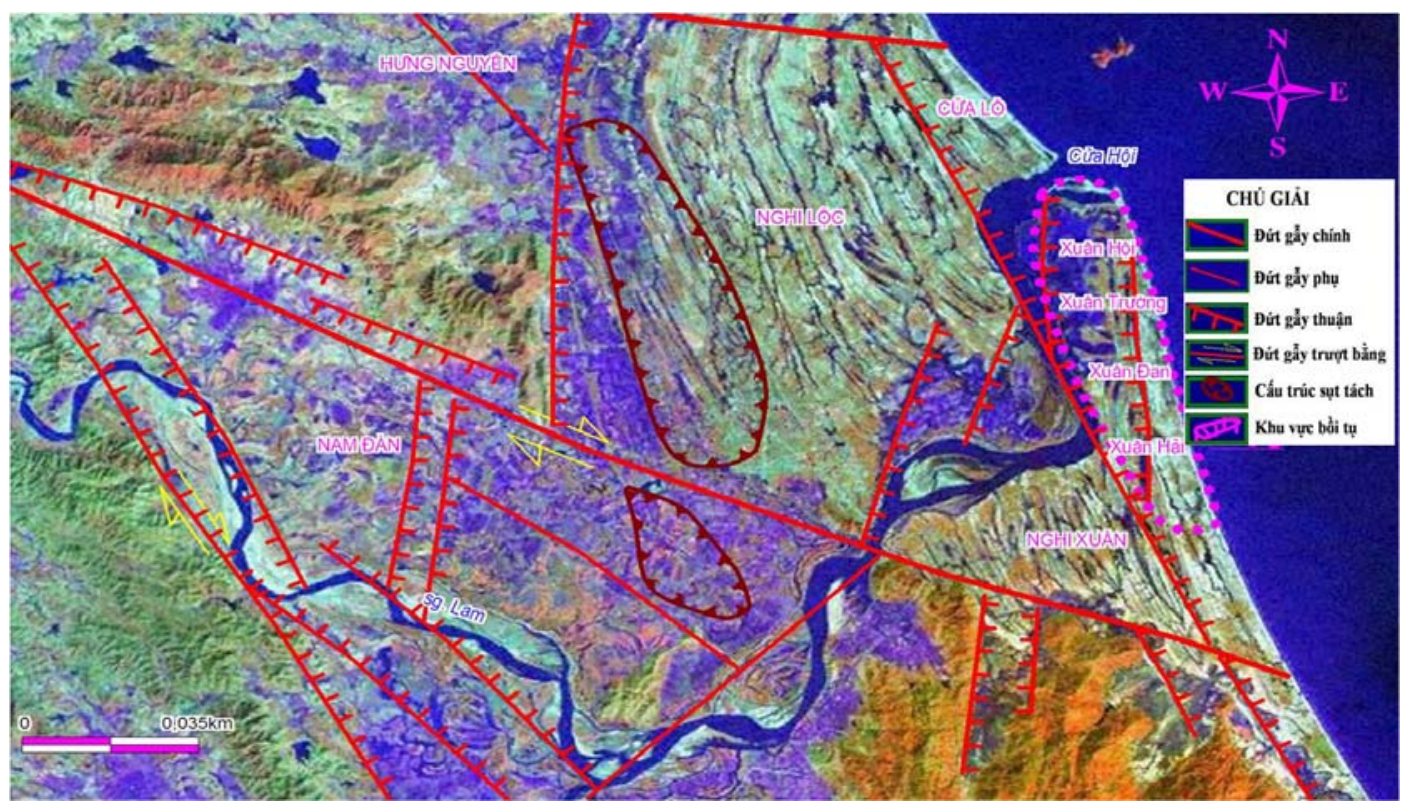

Hình 4. Sơ đồ hiện trạng bồi tụ và đứt gãy hoạt động khu vực cửa Hội - Sông Cả (ảnh Landsat-8)
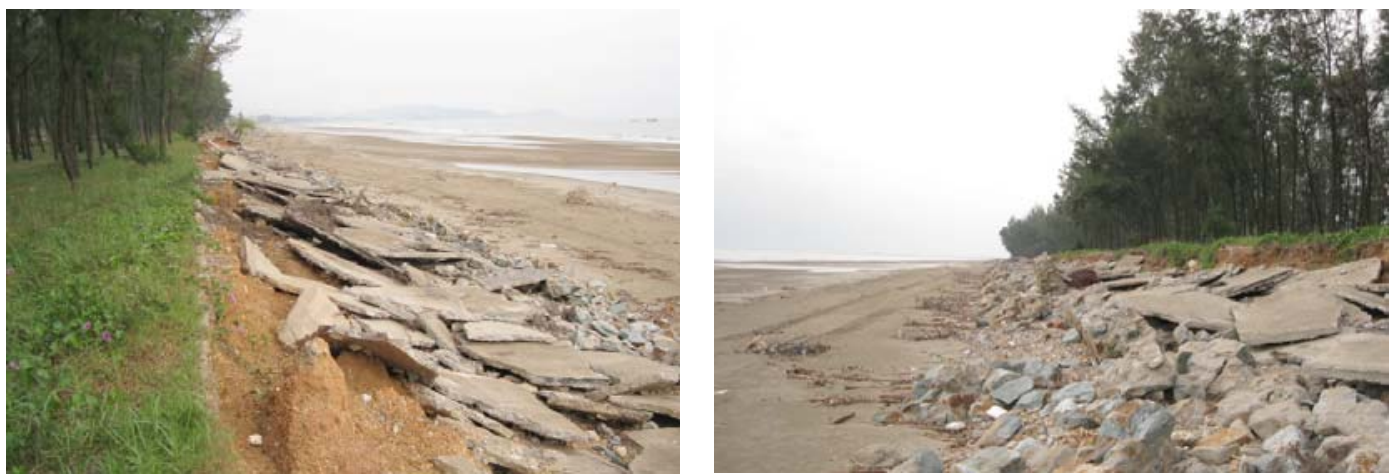

Hình 5. Hiện tượng xói lở 2 bên Cửa Hội (ảnh Nguyễn Công Quân)

Hiện tượng xói lở bờ phía trong sông diễn ra khá phức tạp. Trong những năm 1965-1978, hiện tượng xói lở vùng ven biển diễn ra cả hai phía cửa sông: bên bờ bắc xói lở nhẹ với tốc độ $<1 \mathrm{~m} /$ năm trên các đoạn bờ dài từ 1,2 đến $2,5 \mathrm{~km}$; bên bờ nam xói lở bờ diễn ra mạnh mẽ với tốc độ $>4 \mathrm{~m} /$ năm trên đoạn bờ dài gần $4 \mathrm{~km}$, đoạn xói rộng nhất tới $90 \mathrm{~m}$ và trung bình $15-20 \mathrm{~m}$. Trong năm 1978 đến nay, hiện tượng xói lở tiếp tục diễn ra bên phía bờ nam, trên chiều dài hơn $6 \mathrm{~km}$; ngược lại, bên bờ bắc, xói lở giảm dần và chuyển sang giai đoạn bồi tụ, vùng bồi chính dài $3,2 \mathrm{~km}$ nằm kề cửa sông. 
Tạp chí Các Khoa học về Trái Đất, 38 (1), 46-58

Như vậy, trong vài chục năm qua diễn biến vùng ven biển cửa Hội diễn ra không như nhau: bên bờ bắc (thị xã Cửa Lò, Nghệ An) diễn ra xói lở mạnh sau đó bồi tụ trở lại. Ngược lại, bên phía bờ nam (huyện Nghi Xuân, Hà Tĩnh) diễn ra hiện tượng xói lở bờ biển liên tục trong nhiều năm qua. Hiện tượng xói lở bờ biển cửa Hội xảy ra chủ yếu bên phía bờ nam.

\subsubsection{Của Nhật Lệ (sông Kiến Giang, tỉnh Quảng Bình)}

Cửa Nhật Lệ nằm trên địa phận thành phố Đồng Hới, tỉnh Quảng Bình. Trong những năm qua, hiện tượng xói lở bờ biển diễn ra cả hai phía bờ thuộc cửa Nhật Lệ, xu thế phát triển và đặc điểm xói lở phân dị rõ rệt (hình 6).

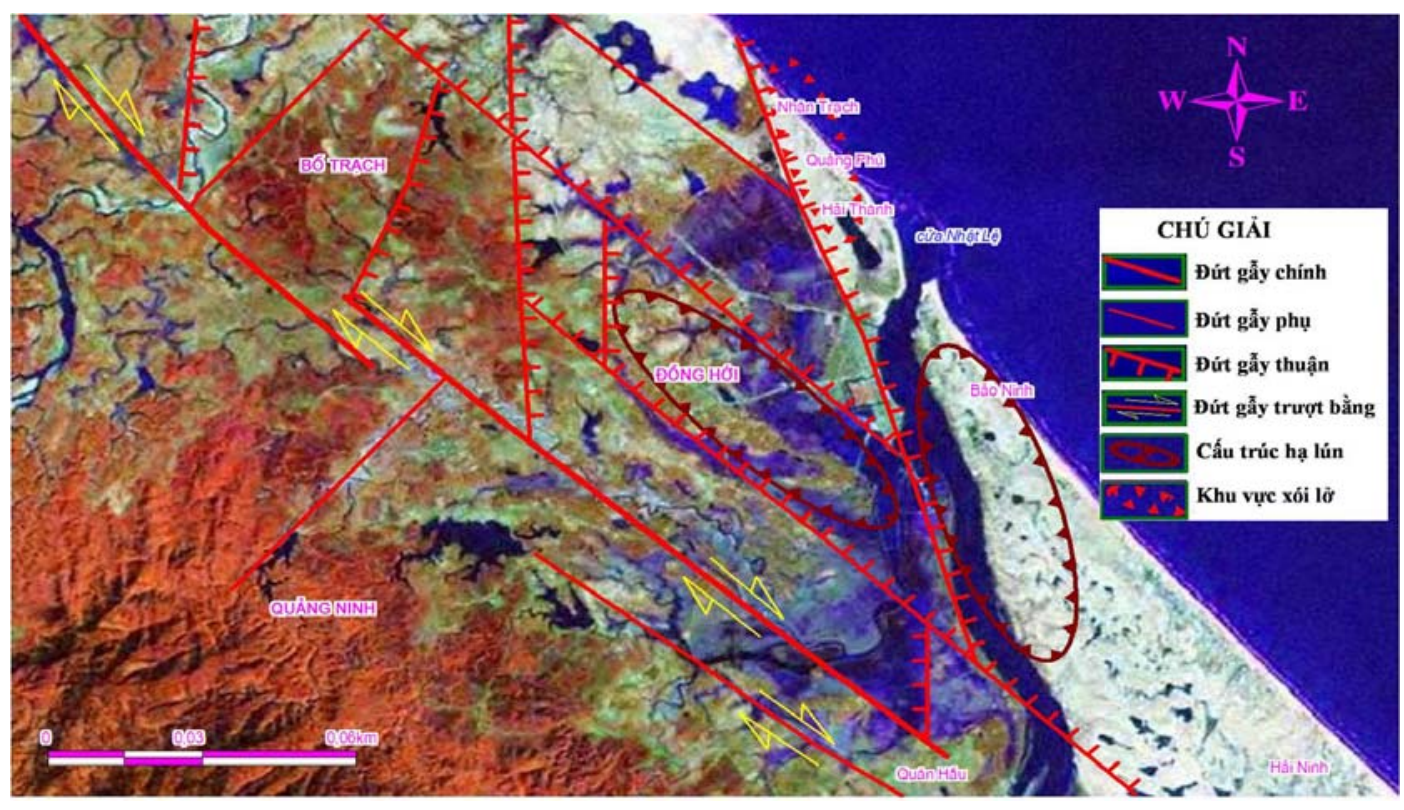

Hình 6. Sơ đồ hiện trạng xói lở và đứt gãy hoạt động khu vực cửa Nhật Lệ - Sông Kiến Giang (ảnh Landsat-8)

Những biến động phía ngoài cửa sông diễn ra không chỉ do tác động của dòng nước lũ, mà còn chịu tác động mạnh mẽ của nhân tố động lực biển (sóng, gió, thủy triều, nước dâng,...). Do cấu trúc bờ biển phẳng với vật liệu cát bở rời rất dễ dịch chuyển do tác động của sóng và dòng chảy ven bờ, nên khu vực ven biển cửa Nhật Lệ biến động theo mùa. Một biến đổi thường gặp ở đây, tương tự như nhiều cửa sông khác ở miền Trung là hiện tượng cửa sông bồi tụ và lấp đầy vào mùa khô; xói lở mở rộng vào mùa nước lũ. Cửa sông biến động mạnh do dòng chảy có tốc độ cao phá hủy các dải cát thấp ven cửa sông. Đoạn ven biển phía bắc cửa Nhật Lệ, hiện tượng xói lở diễn ra mạnh mẽ trong thời gian 1965-1999 tại đoạn bờ biển khu vực Bầu Tró trên chiều dài $1400 \mathrm{~m}$ nằm kề cửa sông. Vùng xói lở rộng trung bình $65-70 \mathrm{~m}$, có thể đạt tới $160 \mathrm{~m}$. Tốc độ xói lở trung bình khoảng $2 \mathrm{~m} /$ năm và lớn nhất tới $5-6 \mathrm{~m} /$ năm. Tiếp theo vùng xói là đoạn bờ biển bồi tụ nhẹ với tốc độ bồi $1-1,5 \mathrm{~m} /$ năm. Các đoạn bờ xói và bồi tụ phân bố xen kẽ nhau. Nhìn chung, trong những năm qua $x u$ thế phát triển đoạn bờ bắc cửa Nhật Lệ thiên về xói lở chân cồn cát cao ven biển. Đoạn bờ biển phía nam cửa Nhật Lệ, hiện tượng xói lở-bồi tụ diễn ra với tốc độ thấp hơn, trung bình khoảng $0,5-1,0 \mathrm{~m} /$ năm. Doi cát cửa sông bên bờ nam có xu thế phát triển kéo dài về phía bắc và luôn thay đổi theo mùa. Xu thế chung của đoạn bờ này là được bồi tụ nhẹ .

Như vậy, hiện tượng xói lở phía bờ bắc cửa Nhật Lệ diễn ra mạnh, có ảnh hưởng trực tiếp tới an toàn của kho nước tại Bầu Tró, là nguồn cung cấp nước ngọt quan trọng của thị xã Đồng Hới. Hiện nay, tốc độ xói lở chân cồn cát ven biển khu vực Bầu Tró đã được hạn chế đáng kể nhờ việc xây dựng một số công trình chống xói lở ở đây. 


\section{P.V. Hùng và nnk/Tạp chí Các Khoa học về Trái Đất, Tập 38 (2016)}

\subsubsection{Cửa Việt (sông Thạch Hãn, tỉnh Quảng Trị)}

Đoạn bờ biển Cửa Việt có các cồn cát cao phân bố song song với đường bờ, giữ vai trò che chắn sóng gió ven biển cho dải đồng bằng thấp nằm phía sau cồn cát. Vùng địa hình thấp ven cửa sông Thạch Hãn thực chất là vùng đầm lầy ven biển đang trong quá trình bồi lấp đầy với hệ thống sông ngòi rất phát triển (hình 7).

Diễn biến xói lở-bồi tụ khu vực Cửa Việt trong những năm qua xảy ra phức tạp. Đoạn lòng dẫn trong sông có đặc điểm biến động mạnh, nhiều đoạn sông bị chặn lấp, nhiều vùng đất thấp ven cửa sông đã được khai thác trồng lúa và xây dựng các ô nuôi thủy sản. Đoạn bờ biển ngoài cửa sông xuất hiện hiện tượng cửa sông bồi tụ có xu thế khép kín. Hiện tượng xói lở bờ biển diễn ra cả hai phía cửa sông, nhưng xu thế và đặc điểm xói lở không như nhau. Đoạn ven biển phía bắc Cửa Việt, trước năm 1965, bờ biển có xu thế bồi tụ lấn ra biển; ngược lại, hiện tượng xói lở diễn ra mạnh mẽ sau năm 1965 trên suốt đoạn dài nằm kề cửa sông. Tốc độ xói lở đạt tới $5-6 \mathrm{~m} / \mathrm{năm}$. Đường bờ biển bị lùi vào lục địa khoảng $140 \mathrm{~m}$ so với vị trí năm 1952 . Đoạn bờ biển phía nam Cửa Việt, hiện tượng xói lở diễn ra với tốc độ thấp hơn, trung bình khoảng $2,0 \mathrm{~m} /$ năm . Doi cát bên bờ nam luôn biến động do dòng chảy lũ. Như vậy, hiện tượng xói lở ở khu vực Cửa Việt cả ở trong đoạn cửa sông và phía ngoài bờ biển đã diễn ra trong suốt thời gian dài gây ảnh hưởng lớn tới khu vực dân cư và tuyến luồng giao thông thủy ra vào cửa sông Thạch Hãn.

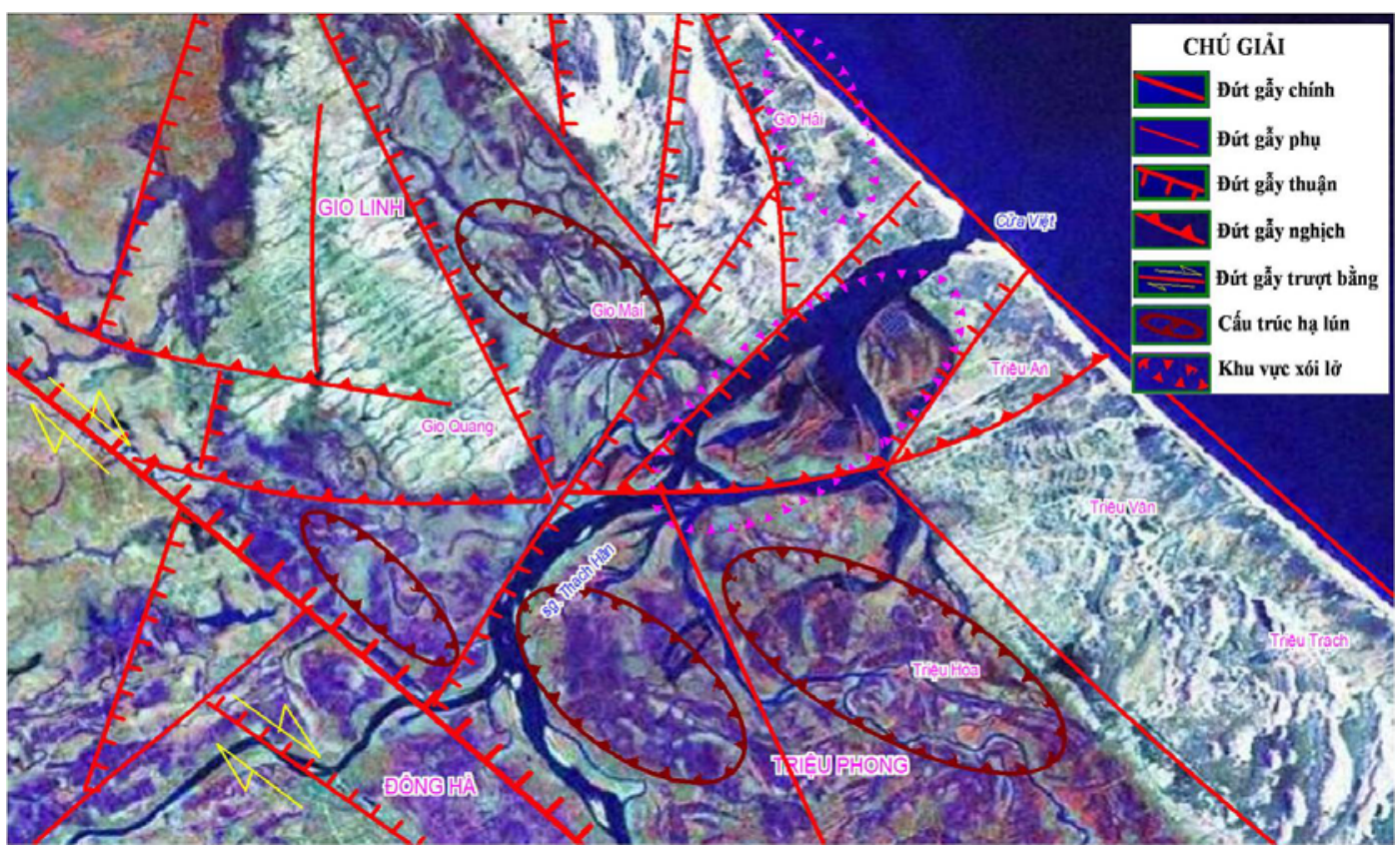

Hình 7. Sơ đồ hiện trạng xói lở và đứt gãy hoạt động khu vực cửa Việt - Sông Thạch Hãn (ảnh Landsat-8) 4.2.5. Cửa Thuận An (sông Hương, tỉnh Thìra
Thiên-Huế)

Trong nhiều năm qua tại vùng cửa biển Thuận An xuất hiện tượng xói lở liên tục chân các cồn cát dọc bờ biển. Đây có thể là dấu hiệu một thời kỳ suy thoái của đường bờ biển do nhiều nguyên nhân khác nhau. Trong đợt mưa lũ lớn cuối năm 1999 đã xẩy ra biến động mạnh mẽ địa hình không chỉ trong sông Hương mà còn cả vùng ven biển, trong đó có sự xuất hiện các cửa biển mới do nước lũ mở ra. Sự xuất hiện cũng như biến động nhanh địa hình ở các cửa biển mới phản ánh một quy luật "tự điều chỉnh lại" của thiên nhiên. Diễn biến xói lở bồi tụ vùng ven biển cửa Thuận An trong hơn những năm qua rất phức tạp. Giai đoạn trước lũ lịch sử tháng 11- 1999, hiện tượng xói lở liên tục diễn ra ở chân bãi cát ven biển cửa Thuận An, 
Tạp chí Các Khoa học về Trái Đất, 38 (1), 46-58

chứng tỏ bờ biển đang trong một giai đoạn suy thoái trầm trọng. Đoạn xói mạnh nhất từ năm 1965 đến 1999 nằm kề thị xã Thuận An; vùng bờ xói có chiều rộng 150-180m, tốc độ xói lở 6,4 m/năm, đã ảnh hưởng lớn tới an toàn khu du lịch và vùng dân cư đang phát triển ở thị xã Thuận An. Tháng 11/1999, ở vùng đầm phá Tam Giang - Cầu Hai, một số dải cát thấp ven biển đã bị phá hủy và mở ra một số cửa biển mới trong đó có khu vực thôn Hải Dương và làng Hoà Duân. Tại vị trí cửa Hoà
Duân, xói lở diễn ra liên tục trong khoảng thời gian dài, chiều rộng cửa $620 \mathrm{~m}$, chỗ sâu nhất tới $7 \mathrm{~m}$. Vị trí cửa Hải Dương là vùng đất thấp phía bắc cửa Thuận An. Khi mới mở cửa này rộng 280m, sau đó tự bồi lại vào cuối năm 1999 - đầu năm 2000. Tình trạng xói lở bờ biển khu vực cửa Thuận An trong những năm qua diễn biến rất phức tạp, có ảnh hưởng lớn tới an toàn các công trình kinh tế, khu du lịch và các vùng dân cư thuộc thị xã Thuận An và xã Hải Dương (hình 8,9 ).

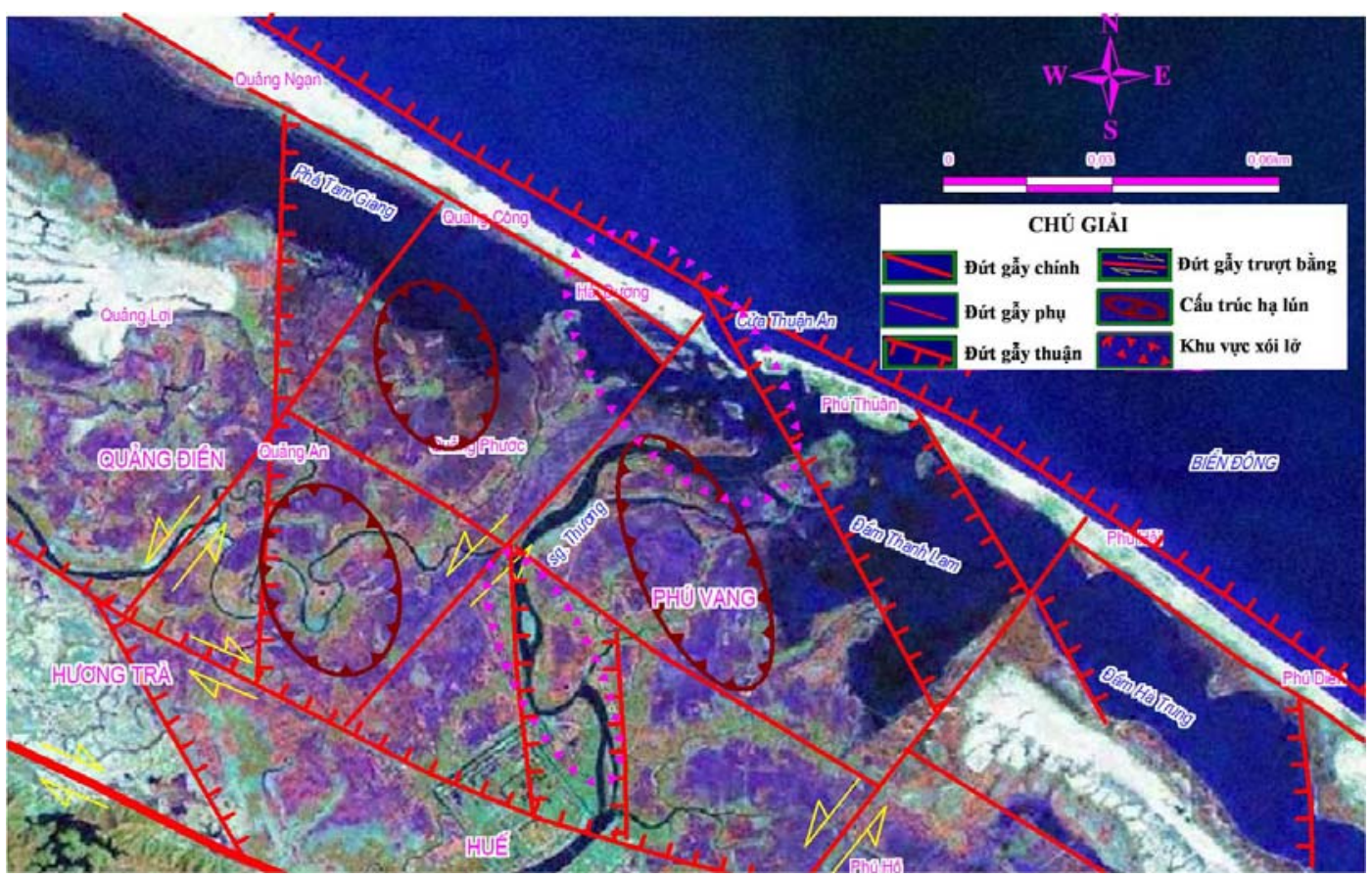

Hình 8. Sơ đồ hiện trạng xói lở và đứt gãy hoạt động khu vực cửa Thuận An - Sông Hương (ảnh Landsat-8)
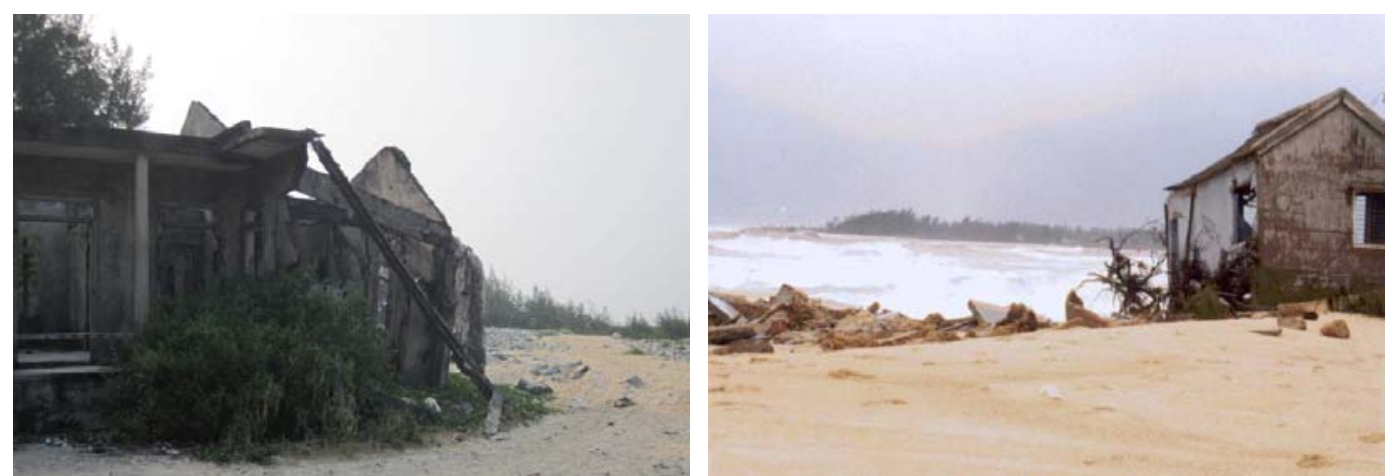

Hình 9. Hiện tượng xói lở cửa Hòa Duân và Thuận An (ảnh Nguyễn Công Quân) 


\section{P.V. Hùng và nnk/Tạp chí Các Khoa học về Trái Đất, Tập 38 (2016)}

\section{Mối quan hệ giữa đứt gãy hoạt động và xói lở bờ biển}

Quá trình xói lở vùng cửa sông ven biển Bắc Trung Bộ diễn ra rất phức tạp và do tác động của các yểu tố nội sinh, ngoại sinh và nhân sinh. Trong đó nổi lên một yếu tố quan trọng, có thể nói là chủ đạo trong phát sinh xói lở VCSVB là chuyển động hiện đại vỏ Trái đất, đặc biệt là đứt gãy hoạt động. Một số công trình đã phân tích vai trò của yếu tố này trong phát sinh xói lở ở VCSVB (Lê Xuân Hồng 1996, Phạm Văn Hùng 2008, Nguyễn Thế Thôn và nnk, 1987). Các công trình đã xác lập mối quan hệ chặt chẽ của đứt gãy hoạt động với xói lở bờ sông, bờ biển. Đó chính là mối quan hệ phát sinh và thúc đẩy xói lở phát triển.

Trên các vùng cửa sông ven biển Bắc Trung Bộ, hầu hết các điểm xói lở đều phân bố dọc các đới đứt gãy hoạt động hoặc ở những nơi đứt gãy cắt ra bờ biển (hình 1 , bảng 1 ). Các đoạn bờ biển bị xói lở mạnh và rất mạnh chủ yếu phân bố ở những điểm giao nhau của các đứt gãy tích cực. Đó chính là những đoạn bờ biển bị phá hủy mạnh mẽ, quá trình xói lở bờ cũng diễn ra mạnh nhất, ví dụ như ở các cửa Lạch Trường, Lạch Ghép, Hới, Thuận An,... Trên đoạn bờ biển phía bắc cửa Lạch Trường thuộc địa phận huyện Nga Sơn, quá trình xói lở diễn ra với cường độ mạnh tại điểm nút giao của các đứt gãy phương TB-ĐN thuộc đới Sơn LaBỉm Sơn và đứt gãy phương ĐB-TN thuộc đới Hoằng Hóa-Nông Cống. Đoạn bờ phía bắc cửa Lạch Ghép là nơi đới đứt gãy Sông Mã cắt ra bờ biển đã thúc đẩy quá trình xói lở phát triển với cường độ mạnh. Các đoạn bờ khác như đoạn bờ Nghệ An-Hà Tĩnh và đoạn bờ Thừa Thiên-Huế cũng tương tự như các đoạn bờ trên. Trên các đoạn bờ này, tại những nơi có đới đứt gãy Sông Cả, Rào Nậy, Đa Krong-Huế cắt ra bờ biển; đoạn bờ cấu tạo bởi các trầm tích bở rời, quá trình xói lở diễn ra với cường độ mạnh. Đặc biệt, tại những điểm nút giao của các đới đứt gãy phương TB- $\mathrm{PN}$ với các đứt gãy có phương ĐB-TN, hoặc á kinh tuyến, quá trình xói lở diễn ra càng mạnh. Tuy nhiên, quá trình xói lở hầu như không diễn ra ở những nơi mà cấu tạo bờ bởi đá gốc rắn chắc, mặc dù có đứt gẫy hoạt động cắt qua.

Bảng 1. Tổng hợp các đứt gãy hoạt động chính ở vùng cửa sông ven biển Bắc Trung Bộ

\begin{tabular}{|c|c|c|c|c|c|c|c|c|c|}
\hline STT & $\begin{array}{l}\text { Tên đới } \\
\text { đứt gãy }\end{array}$ & Mặt trượt & Tính chất & ĐM, ĐC & ĐĐ Msmax & ĐH & $Đ N$ & $\mathrm{XL}$ & VCSVB bị ảnh hưởng \\
\hline 1 & ĐSM & ĐB, $60-70^{\circ}$ & Bp-T & + & $5,1-5,5$ & + & + & M & $\begin{array}{l}\text { Cửa Lạch Trường và Lạch } \\
\text { Ghép, Sông Mã (Thanh Hóa) }\end{array}$ \\
\hline 2 & ĐSC & ĐB, $60-70^{\circ}$ & Bp-T & + & $5,1-5,5$ & + & + & M & $\begin{array}{l}\text { Các cửa Lò, Hội và cửa Sót, } \\
\text { Sông Cả (Nghệ An-Hà Tĩnh) }\end{array}$ \\
\hline 3 & ĐRN & ĐB, $60-80^{\circ}$ & Bp-T & + & $5,1-5,5$ & + & + & $\mathrm{Y}$ & $\begin{array}{l}\text { Cửa Gianh, Sông Gianh } \\
\text { (Quảng Bình) }\end{array}$ \\
\hline 4 & ĐKG-VL & ĐB, $60-70^{\circ}$ & Bp-T & + & $5,1-5,5$ & + & + & TB & $\begin{array}{l}\text { Cửa Tùng, Sông Bến Hải } \\
\text { (Quảng Trị) }\end{array}$ \\
\hline 5 & ĐĐK-H & ĐB, $60-70^{\circ}$ & Bp-T & + & $5,1-5,5$ & + & + & M & $\begin{array}{l}\text { Cửa Thuận An, Sông Hương } \\
\text { (Thừa Thiên-Huế) }\end{array}$ \\
\hline
\end{tabular}

Chú thích: Các đới đứt gãy: ĐSM- Đới đứt gãy Sông Mã; ĐSC - Đới đứt gãy Sông Cả, ĐRN - Đới đứt gãy Rào Nậy, ĐKG-VL Đới đứt gãy Khe Giữa - Vĩnh Linh, ĐĐK-H - Đới đứt gãy Đa Krông-Huế. ĐB, 60-80- Hướng đổ và góc dốc mặt trượt đứt gãy. Bp$\mathrm{T}$ - Trượt bằng phải-thuận. Dấu hiệu hoạt động của đứt gãy: ĐM, ĐC- Có biểu hiện biến dạng địa mạo, địa chất; ĐĐ- Tiềm năng sinh động đất; $Đ H-$ Có biểu hiện dị thường địa hóa khí đất $(\mathrm{Hg}, \mathrm{Rn})$; $Đ \mathrm{~N}-\mathrm{Có}$ biểu hiện dị thường địa nhiệt, xuất lộ nước khoáng nóng; XL - Xói lở. Mức độ xói lở: M- Mạnh, TB- Trung bình, Y- Yếu. VCSVB- Vùng cửa sông ven biển

Như vậy, chuyển động hiện đại vỏ Trái Đất, hoạt động phá hủy của đứt gãy tích cực đã phá hủy đường bờ, làm thay đổi hình thái đường bờ rất rõ nét. Hoạt động hạ lún diễn ra dọc các đứt gãy trượt bằng - thuận và thuận đã tác động trực tiếp đến quá trình xói lở vùng cửa sông ven biển. Chuyển động hạ lún đã làm cho biển tiến vào sâu trong lục địa, năng lượng động lực dòng ven bờ tăng lên và quá trình xâm thực ngang của sông mạnh lên đáng kể. Hoạt động của các đới đứt gãy đã phá hủy đất đá tạo những đoạn đường bờ có cấu tạo bởi vật liệu bở rời rất dễ bị xói lở, cuốn trôi mang đi nơi khác. Khi vận tốc dịch chuyển của đứt gãy lớn, quá trình phá hủy đất đá cũng như tốc độ hạ lún mạnh, càng làm cho quá trình xâm thực ngang mạnh lên, do đó tốc độ xói lở bờ biển càng mạnh hơn. Mặt khác, trên các cấu trúc hạ lún hiện đại, nguồn vật liệu do sông mang ra, cũng như ngoài biển mang vào với lượng lớn, tốc độ bồi lắng lớn hơn tốc độ hạ lún sẽ dẫn đến khu vực đó phát triển quá trình bồi tụ. 
Tạp chí Các Khoa học về Trái Đất, 38 (1), 46-58

\section{Kết luận}

Khu vực nghiên cứu nằm trong vùng hoạt động kiến tạo hiện đại diễn ra mạnh mẽ. Trên khu vực này phân bố các đới đứt gãy hoạt động có phương TB-ĐN, ĐB-TN, á kinh tuyến và á vỹ tuyến. Trong đó, phải kể đến các đoạn đầu mút đông nam của các đới đứt gãy có phương TB-ĐN: Sơn LaBỉm Sơn, Sông Mã, Sông Cả, Rào Nậy, Khe GiữaVĩnh Linh và Đa Krông-Huế. Ngoài ra, các đới đứt gãy phương ĐB-TN phân bố chủ yếu ở phía bắc, á kinh tuyến ở phía nam khu vực Bắc Trung Bộ. Trong bối cảnh địa động lực hiện đại nén ép theo phương á kinh tuyến, kiểu trường "Trượt-Giãn", các đới đứt gãy Sơn La-Bỉm Sơn, Sông Mã, Sông Cả, Rào Nậy, Khe Giữa-Vĩnh Linh và Đa KrôngHuế hoạt động trượt bằng phải-thuận, phương á kinh tuyến hoạt động thuận-tách.

Hoạt động tích cực của các đới đứt gãy kiến tạo và chuyển động hạ lún hiện đại cục bộ của vỏ Trái Đất là một trong những yếu tố chủ đạo phát sinh tai biến xói lở vùng cửa sông ven biển Bắc Trung Bộ. Phần lớn các điểm xói lở đều phân bố tại những nơi có đới đứt gãy hoạt động cắt qua: xã Hải Lộc-Hậu Lộc, Hải Thịnh-Tĩnh Gia, Diễn Hải, Diễn Kim, Diễn Thịnh-Diễn Châu, Cảnh Dương, Quảng Phúc-Quảng Trạch, Cửa Thuận An- Hương Trà và Hương Thủy. Quá trình xói lở xảy ra với tốc độ và cường độ mạnh, rất mạnh đều trùng với những đoạn bờ biển nằm trong phạm vi ảnh hưởng động lực đứt gãy hoạt động mạnh, hoặc ở những điểm nút giao nhau của các đới đứt gãy hoạt động. Tại những nơi này, cấu tạo bờ là các trầm tích bở rời, quá trình xói lở bờ sông, bờ biển có điều kiện phát triển thường xuyên và với tốc độ lớn.

\section{Tài liệu dẫn}

Nguyễn Văn Cư và Phạm Huy Tiến, 2003: Sạt lở bờ biển miền Trung Việt Nam, Nxb. Khoa học và Kỹ thuật, Hà Nội, 200tr.

Lê Xuân Hồng, 1996: Đặc điểm xói lở bờ biển Việt Nam. Luận án Phó tiến sỹ Khoa học Địa lý-Địa chất, Hà Nội.

Phạm Văn Hùng, 2006: Đặc điểm hoạt động của các đứt gãy ở khu vực Hồ Kẻ Gỗ-Sông Rác trong Đệ tứ-Hiện đại. Tạp chí Khoa học, số 2A, Đại học Quốc gia Hà Nội, tr.40-50, Hà Nội.

Phạm Văn Hùng, 2008: Đặc điểm đứt gãy hoạt động và tai biến xói lở bờ biển Duyên hải Nam Trung Bộ. Tạp chí Các Khoa học về Trái Đất, T.28, 4, tr.314-322.

Nguyễn Văn Hùng, 2002: Đặc điểm cơ bản đứt gãy tân kiến tạo vùng Tây Bắc Việt Nam. Luận án Tiến sỹ Địa chất, Viện Địa chất, Hà Nội.

Bùi Văn Thơm, 2002: Đặc điểm đứt gãy tân kiến tạo khu vực Bắc Trung Bộ. Luận án Tiến sỹ Địa chất, Viện Địa chất, Hà Nội.

Nguyễn Thế Thôn, Lưu Hải Thống, Lê Đức An, Lại Huy Anh, Nguyễn Thượng Hùng, 1987: Vấn đề chuyển động nâng hạ và nguyên nhân gây xói lở vùng bờ biển Hải Hậu. Tạp chí Các khoa học về Trái Đất, T.9, 3, tr.84-88.

Nguyễn Đình Xuyên, Nguyễn Ngọc Thủy, 1997: Tính động đất và độ nguy hiểm động đất trên lãnh thổ Việt Nam. Thành tựu nghiên cứu Vật lý Địa cầu, Nxb. Khoa học và Kỹ thuật, tr.34-91, Hà Nội.

Nguyễn Trọng Yêm và nnk, 2006: Nghiên cứu xây dựng bản đồ tai biến môi trường tự nhiên lãnh thổ Việt Nam. Báo cáo tổng kết Đề tài cấp Nhà nước, mã số KC-08-01, lưu trữ Viện Địa chất, Hà Nội. 